
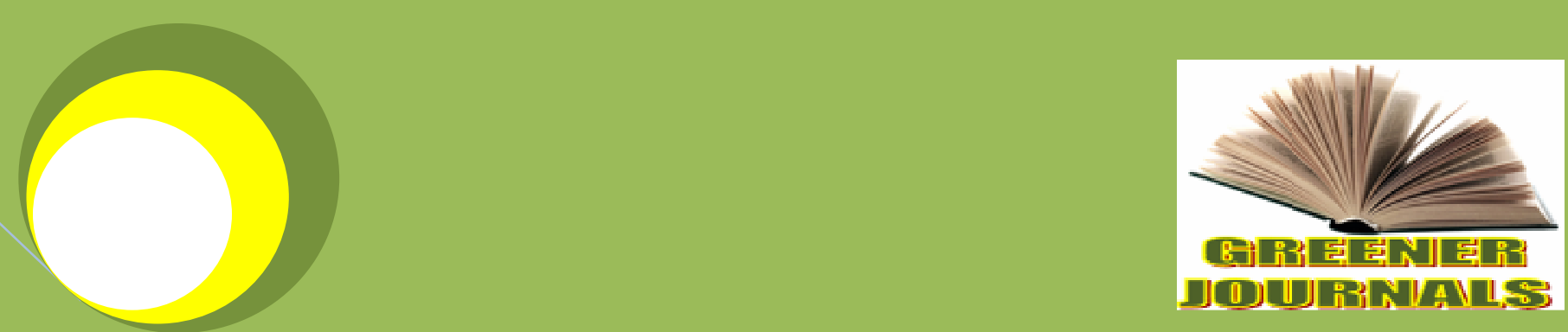

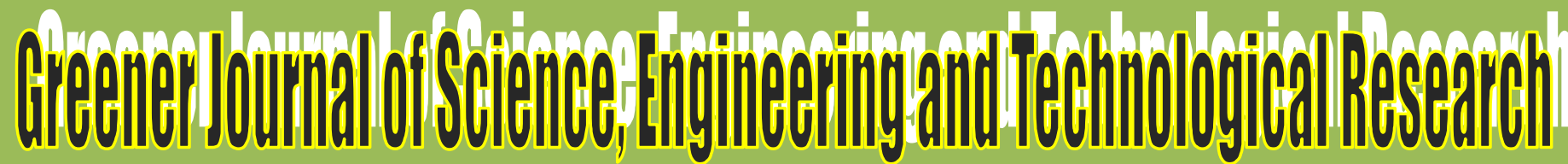
ISSN: 2276-7835 ICV: 5.62

\title{
Determination of \\ Physico-Chemical Pollutant Levels in Water Sample from Alau Dam, Borno State, Nigeria
} By

Peter Auta Gwaski Alhassan Ali Gadam 


\title{
Determination of Physico-Chemical Pollutant Levels in Water Sample from Alau Dam, Borno State, Nigeria
}

\author{
Peter Auta Gwaski ${ }^{1}$ and Alhassan Ali Gadam²
}

\author{
${ }^{1}$ Department of Science Laboratory Technology, Ramat Polytechnic Maiduguri, Nigeria. \\ ${ }^{2}$ Department of Pre-ND Science, Ramat Polytechnic, Maiduguri, Nigeria. \\ *Corresponding Author's Email: alhmodubuk@ gmail.com
}

\begin{abstract}
The physico-chemical evaluation of pollutants in water sample from Alau Dam, Borno State was conducted in July, 2014. The parameters (turbidity, temperature, total dissolved solid (TDS), electrical conductivity (E.C) and pH were determined using standard procedures. Also heavy metals $(\mathrm{Cd}, \mathrm{Cr}, \mathrm{Cu}, \mathrm{Mn}$ and $\mathrm{Zn}$ ) were determined by Flame Atomic Absorption Spectropheotometry (FAAS). The results of the analysis showed that temperature was $28.8^{\circ} \mathrm{C}$, total dissolved solid (TDS) was $63 \mathrm{ppm}$, electrical conductivity (E.C) was $130 \mu \mathrm{s} / \mathrm{cm}$, turbidity was $78.0 \mathrm{NTU}$ and $\mathrm{pH}$ was 7.5 . While the concentration levels of heavy metals were $\mathrm{Cd}(0.02) \mathrm{mg} / \mathrm{l}, \mathrm{Cr}(0.15) \mathrm{mg} / \mathrm{l}, \mathrm{Cu}(0.48) \mathrm{mg} / \mathrm{l}, \mathrm{Mn}(0.07) \mathrm{mg} / \mathrm{l}$ and $\mathrm{Zn}(0.28) \mathrm{mg} / \mathrm{l}$. The results showed presence and concentration levels of all the parameters analyzed and were within the maximum levels set by WHO and NAFDAC, except for $\mathrm{Cd}$ and $\mathrm{Cr}$ that exceeded the permissible limits which are a cause of concern, as consumption of water and other aquatic life from the study area may cause health hazard to human. Based on the findings, close monitoring, involving human heath risk assessment in relation to environmental pollution of Alau Dam is recommended.
\end{abstract}

Key words: FAAS, Alau Dam, heavy metal, pollutant and waste water.

\section{INTRODUCTION}

Water is essential to all living organisms and in all aspects of human life. Unfortunately, the availability of quality water has been impacted upon by both natural and anthropogenic sources, leading to poor water quality of productivity and aquatic ecosystems (FAO, 1992). The rapid industrialization coupled with technological advances in agriculture, have introduced various pollutants (synthetic and organic) into the aquatic ecosystem, which serves as the ultimate sink for most metals (Ogbeibu and Ezeunara, 2002). The provision of water for domestic and other uses in rural and urban centers is one of the most intractable problems in Nigeria today. Access to adequate water of good quality is essential to health, food production and sustainable development. Every human use of water, whether for drinking, irrigation and industrial processes or for recreation has some minimum quality requirements in order to make it acceptable in which the quality criterion can be described in terms of physical, chemical and biological properties of such water. According to the World Commission on Water for the $21^{\text {st }}$ Century, more than half of the world's major rivers, lakes and streams are depleted and polluted, that they endanger human health and poison surrounding ecosystems (Inter-Press, 1999). The sources of water pollution vary and involve almost every significant human activity which includes dumping of domestic wastes, sewage, agricultural wastes and industrial influents into water bodies contaminating it and becoming toxic and carcinogenic. Waste water, streams and lakes containing heavy metals are produced by many manufacturing processes and find their way into the environment (Soon et al. 1980, Dasher, 1986, Oguzie, 1996; Ogbeibu and Ezeunara, 2002). Heavy metals which are chemical elements with specific gravity that is at least five times the specific gravity of water have long been recognized as serious pollutants of the aquatic environment. These are also natural tree components of the aquatic environment, but background levels in the environment have increased especially in areas where industrial, agricultural and mining activities are widespread (Bryan and Langston, 1992). Heavy metals released into the environment find their way into the aquatic system as a result of direct input, atmospheric deposition and surface runoffs. The increased use of metal-based fertilizer in agricultural revolution has resulted in continued rise in concentration of metal pollution in fresh water reservoir due to water runoff. Also faecal pollution of drinking water causes water borne diseases which lead to the death of millions of people both in cities and villages (Asaolu, 1998). Discharge of toxic metals into the lake from intensive agricultural activities (fishing and farming), domestic water and river water translocation of toxics 
accumulate in the water bodies and tissues of other aquatic lives posing long-term toxic effects on human health when consumed. Based on the above, the aim of the study is to evaluate some physico-chemical parameters of water sample from Alau Dam - the study area.

\section{MATERIALS AND METHODS}

\section{Study Area}

Borno State is located in the North-Eastern geographical zone of Nigeria between latitude $10^{\circ}$ and $14^{\circ} \mathrm{N}$ and longitude $11^{\circ} 30^{\prime}$ and $14^{\circ} 45^{\prime} \mathrm{E}$ which lies in the sahelian vegetational belt south of the sahara with less than $600 \mathrm{~mm}$ of rain annually (World Atlas, 2005). The major activities practiced in the area are fishing and farming characterized with diverse usage of harmful chemicals (pesticides and herbicides). Sample of water was collected from Alau dam where fishing and farming activities were intensively practiced.

\section{Sample and Sampling}

Surface water sample was collected from the study area at four established locations at the depth of $15 \mathrm{~cm}$ in the month of July 2014. Sampling procedures was guided by details (Radojevic and Bashkin, 2006). The water sample was collected in pre-cleaned plastic container, labeled and preserved in the refrigerator at $30^{\circ} \mathrm{C}$ to prevent breakdown of chemical by UV-light before analysis.

\section{Sample Preparation}

Water sample collected for heavy metals determination was digested (Radojevic and Bashkin, 2006). Accurately, $100 \mathrm{~cm}^{3}$ of water sample was measured and transferred in $250 \mathrm{~cm}^{3}$ beaker and was acidified with $5 \mathrm{~cm}^{3} \mathrm{conc}$. $\mathrm{HNO}_{3}$. It was then heated to evaporation on a hot plate for 10 minutes to $20 \mathrm{~cm}^{3}$ and further acidified by adding $60 \mathrm{ml}$ conc. $\mathrm{HNO}_{3}$ and $40 \mathrm{ml}$ conc. $\mathrm{HClO}_{4}$ in the ratio 3:2. The mixture was heated almost to clear solution. The resultant volume was cooled, filtered and made up to $100 \mathrm{~cm}^{3}$ mark of volumetric flask with distilled water. Also sample blank was simultaneously prepared.

\section{Analysis of Samples}

\section{Determination of temperature $\left({ }^{\circ} \mathrm{C}\right)$ and $\mathrm{pH}$ of surface water}

Temperature and $\mathrm{pH}$ of surface water were determined on site. The Elico (CL 513) digital $\mathrm{pH}$ meter was calibrated using buffers of $\mathrm{pH} 4.0,7.0$ and 10.0 for the determination of $\mathrm{pH}$. Glass bulb mercury thermometer was calibrated by a two-phase system test using ice water at $\mathrm{O}^{\circ} \mathrm{C}$.

\section{Determination of Total Dissolved Solids}

It was determined by pipetting $200 \mathrm{ml}$ of a thoroughly mixed sample and filterate through a glass fibre filter with applied vacuum. The sample was washed with three successive $10 \mathrm{~cm}^{3}$ of reagent grade distilled water. The filterate was evaporated and weighed on an evaporating dish to dryness in an oven for 1 hour at $160^{\circ} \mathrm{C}$, cooled in a dessicator to a stable temperature and weighed. Similarly, the circle of drying, cooling and weighing continued until a constant weight was obtained. TDS was estimated as:

$$
\mathrm{TDS}_{\mathrm{mg} / \mathrm{l}}=\quad \frac{(\mathrm{A}-\mathrm{B}) \times 1000}{\text { Volume of sample }(\mathrm{ml})}
$$

Where $A-$ is the weight of filter + dried residue and $B$ is weight of filter paper

\section{Determination of Electrical Conductivity (EC)}

A sample cell was filled with water sample to $25 \mathrm{ml}$ mark, the switch of the HANNA was turned on. The sensitive probe was inserted into the sample water using the set/hold button scroll to get the parameters, the instrument then displayed the conductivity value. 


\section{Determination of Turbidity}

The sample cell was thoroughly washed and rinsed with the water sample, then $10 \mathrm{ml}$ of the sample was poured and covered. It was then slot into the chamber of the instrument and the power was turned on, and displayed the reading.

\section{Determination of Metals in Water Sample}

The standard method of flame atomic absorption spectrophotometry (FAAS) was employed for determining the heavy metal analytes (Cd, Cr, Cu, Mn and Zn) (SC 2000). The Shimadzu Atomic Absorption Spectrophotometer AA6800 operational with an ASC-6100 auto sampler and air acetylene atomization gas mixture system was used for the analysis.

\section{RESULTS AND DISCUSSIONS}

Table 1: Shows the levels of physical parameter of the surface water sample

\begin{tabular}{|l|l|}
\hline Parameters & Values of the physical param eters \\
\hline Temperature $(\mathrm{oC})$ & 28.5 \\
$\mathrm{pH}$ & 7.5 \\
Total Dissolved Solid $(\mathrm{mg} / \mathrm{l})$ & 63 \\
Electrical Conductivity $(\mu \mathrm{s} / \mathrm{cm})$ & 130 \\
Turbidity (NTU) & 78.0 \\
\hline
\end{tabular}

Table 2: Shows concentration levels in $\mathrm{mg} / \mathrm{l}$ of heavy metals in surface water sample

\begin{tabular}{|l|l|}
\hline Parameters & Concentration $(\mathrm{Mg} / \mathrm{l})$ of the parameter \\
\hline $\mathrm{Cd}$ & 0.02 \\
$\mathrm{Cr}$ & 0.15 \\
$\mathrm{Cu}$ & 0.48 \\
$\mathrm{Mn}$ & 0.07 \\
$\mathrm{Zn}$ & 0.28 \\
\hline
\end{tabular}

\section{DISCUSSION}

The table 1 presents the physical parameters of temperature and $\mathrm{pH}$ where their levels fall within the acceptable ranges of $\mathrm{WHO}$ and NAFDAC for drinking water and aquatic lives. The values of temperature $28.5^{\circ} \mathrm{C}$ and $\mathrm{pH} 7.5$ were in agreement with that presented by Peter et al. 2013). The values for Total Dissolved Solid (TDS) and electrical conductivity were below the WHO acceptable limits of $100 \mathrm{mg} / \mathrm{l}$ and $400 \mu \mathrm{s} / \mathrm{cm}$ respectively. However, the value of turbidity was higher than the maximum limit of 5 NTU which could be attributed to both volume and degree of effluents pollution around the Dam. Also, a similar study was conducted and high turbidity value has been reported at brewery and rubber factory effluents point source of Ikpoba river (Ogbeibu and Ezeunara, 2002; Oguzie, 2003).

Table 2 showed the concentration levels of heavy metals with respect to $\mathrm{Cd}, \mathrm{Cr}, \mathrm{Cu}, \mathrm{Mn}$ and $\mathrm{Zn}$. The heavy metals analysed in the water sample showed varied concentrations with the sequence of metals' concentrations in the order $\mathrm{Cu}>\mathrm{Zn}>\mathrm{Cr}>\mathrm{Mn}>\mathrm{Cd}$. Copper has the highest concentration level of $0.48 \mathrm{mg} / \mathrm{l}$, this could be attributed to dumping of refuse that contain copper base materials and using fertilizer that contain copper. Also, the high concentration of copper metal in the sample could be due to high organic matter and low dissolved oxygen content, since copper can easily be absorbed on particulate organic matter or aquatic environment (Bryan and Langston, 1992). It has also been observed that the higher concentration of copper could be as a result of weathering of soil along the river basin (Eneji, 2012). The concentration level of cadmium has the lowest value of $0.02 \mathrm{mg} / \mathrm{l}$ which is slightly above the WHO recommended level of $0.005 \mathrm{mg} / \mathrm{l}$ (Olagire and Imeokparia, 2000). The values for manganese $(\mathrm{Mn}) 5.0 \mathrm{mg} / \mathrm{l}$ and Zinc $(\mathrm{Zn}) 0.5 \mathrm{mg} / \mathrm{l}$ were both below the permissible limit set by WHO. Manganese serves as a component of the enzyme system, bone development and metabolism of fatty acid (Jack, 1994).

Van-Der Berg et al. (1987) reported that organic complexation controls the concentration of dissolved zinc in aquatic environment. Zinc also is essential for growth of aquatic organisms and its concentration is affected by Plankton communities (Masoud et al. 2005). Thus, the kinetics of removal of zinc in aquatic systems is strongly 
affected by the rates of biological process. Based on the results of the water sample analysed, Alau Dam is safe for agricultural (fishing and farming) activities but not for human consumption.

\section{CONCLUSION}

The results of the study showed that Alau Dam contains varied concentration levels of heavy metals, of which most of the metals analysed were within the permissible limit set by WHO and NAFDAC. Heavy metal contamination of water of the dam has not reached hazardous levels enough to render the water, fishes and other aquatic organisms unfit for human consumption. However, because of the short period covered by the study, further studies for a longer period to monitor and assess human health risks in relation to environmental pollution of the dam is strongly recommended.

\section{REFERENCES}

Asaolu, S.S. (1998). Chemical pollution studies of coastal water of Ondo State, Ph.d Thesis. Federal University of Technology, Akure.

Bryan, G.W. and Langston, W.J. (1992). Bio-availability, accumulation and effects of heavy metals in water sediment with special reference to the United Kingdom Estuaries: A Review. Environmental Pollution 176: 89-95.

Eneji, I.S. and Sha'Ato, R. (2002). One cycle seasonal variation of heavy metal concentration in River Benue. J. Chem. Soc. Nigeria, Vol. 37, No.2: 102-107.

FAO, Food and Agricultural Organization (1992). Report of the third session of working party on pollution and fisheries, Accra-Ghana, 25 $5^{\text {th }}-29^{\text {th }}$ November, 1991. FAO Fisheries Report 41: 43 Inter Press Service (IPS) (1999). Most rivers on the world are polluted, Washington D.C. Inter Press service, Wire service pp. 38-41

Jack, B. (1994). Chemistry in your environment. Pub. Album. Chichester pp. 144-149.

Masoud, M.A, Elewa, A. E.S., Ali, A.E. and Mohammed, E.A. (2005). Distirbution of some metal concentrations in water and sediments of Lake Edku, Egypt. Bulletin of the Chemists and Technologist of Macedonia, 24 (1): 2134.

NAFDAC (2001). International drinking water guideline consumer safety bulletin, Oct-Dec, 19 Edition, IPAN Khabo Pres, p.68.

Ogbeibu, A.E. and Ezeunara, O. (2002). Ecological impact of brewing effluent on Ikpoba River using the fish communities as bio-indiator. J. Agua. Rs. 17: 35-44

Oguzie, F.A. (1996). Heavy metals in water and effluent of lower Ikpoba River in Benin City, Nigeria. Pak. Journ. Sci. Ind. Res. Vol. 46 (3) 156-160.

Olajire, A.A. and Imeokparia, F.E. (2000). A survey of the water quality of the Osun River: Metal monitoring and geochemistry, Bulletin of the Chemical Society of Ethiopia. 14 (1): 91-108

Peter, A.G., Stephen, S.H. Naomi, P.N. and Victor, O.O. (2013). Emergent pollution Bio-monitoring Triad target species Tissues. Analyte for the aquatic environment of Lake Chad. Advances in Applied Sciences Research 20134 (2).

Radojevic, M. and Bashkin, V.N. (2006). Practical environmental analysis (2 ${ }^{\text {nd }}$ Edn.). RSC Publishing, UK, pp. 248257.

Rai, U.U. and Amust, P. (1976). Health hazard of heavy metal pp. 1-5.

S.C Shimadzu Corporation (2000). Atomic Absorption Spectrometry Cookbook: Food Analysis, Analytical Instrument Division, Kyoto Japan, G10, 1-32.

Soon, Y.K., Bates, T.E. and Moyer, J.R. (1980). Land application of chemically treated sewage sludge III. Effects of soil and plant heavy metal Content. J. Environ. Qual. 9: 260-273

WHO (2006). Drinking water quality guidelines, International Standard for Drinking Water, $4^{\text {th }}$ Edn. Geneva 615

World Atlas (2005). Physical map of Africa. http://www.encartamap/20.africa.

Cite this Article: Peter AG and Alhassan AG (2017). Determination of Physico-Chemical Pollutant Levels in Water Sample from Alau Dam, Borno State, Nigeria. Greener Journal of Science Engineering and Technological Research, 7 (2): 025-028, http://doi.org/10.15580/GJSETR.2017.2.011217003 